\title{
TOURISM CLIMATE CONDITIONS IN THE WESTERN SUDETES (POLAND) IN RELATION TO UTCI
}

\author{
Bartłomiej Miszuk (D) \\ Institute of Meteorology and Water Management \\ National Research Institute \\ ul. Parkowa 30, 51-616 Wrocław: Poland \\ e-mail: Bartlomiej.Miszuk@imgw.pl
}

\begin{abstract}
The region of Western Sudetes is one of the most popular tourist areas in Poland. Simultaneously, it is also characterized by significant variability in terms of climate conditions. Therefore, the main goal of the analysis was to evaluate variability in heat stress frequency according to UTCI and examine how it corresponds to the results of the tourism-climate index (WSI). The results for both indices, for 1971-2015 data, showed significant differences between the summit and the lower located mountain zones. Analysis on multiannual trends of UTCI classes showed significant increase in the frequency of thermoneutral conditions and decreasing tendency for cold stress categories.
\end{abstract}

\section{Key words}

bioclimate • Sudetes $\cdot$ UTCI $•$ WSI

\section{Introduction}

The Western Sudetes are one of the most outstanding regions of Poland in terms of climate conditions. They are located in the south-west Poland (Lower Silesia) and include the Giant Mts. and Isera Mts. Such a location makes them exposed to frequent advection of polar air masses from the Atlantic Ocean. Consequently, it results in specific precipitation and fog conditions that are significantly different from other regions of Poland. In terms of the influence of weather on human organism, the most crucial aspect is related to very high wind speed, noticed especially in the summit zone of the mountains. Analysis focused on wind conditions of the discussed region showed that the highest parts of the Giant Mts. is one of the most windy regions in whole Europe (Błaś \& Sobik, 2005). Mean annual wind speed on Śnieżka reaches $12.7 \mathrm{~m} \cdot \mathrm{s}^{-1}$ (Otop \& Miszuk, 2011; Błażejczyk, 2019), significantly exceeding values noticed in the surrounding areas. In terms of thermal conditions, mean air temperature in the Western Sudetes varies from about $7.5^{\circ} \mathrm{C}$ in their lower parts to $0.8^{\circ} \mathrm{C}$ on Śnieżka Mtn. It should be also emphasized that over 300 foggy days 
are noticed on Śnieżka throughout the year what additionally intensifies thermal senses because of specific humidity conditions. Therefore, the summit zone of the mountains is characterized by very severe conditions.

The Western Sudetes are also the most important tourist area in the Lower Silesia and one of the most popular tourist region in Poland. Over $90 \%$ of visitors usually stay there for at least three days (Rogowski, 2015). In case of the summit zone (Śnieżka), the number of entries in 2015 reached 650,000, making Śnieżka the most popular destination of the region (Rogowski, 2018). One of the most important tourist aspects is skiing. The Western Sudetes are very popular for both downhill and cross-country skiing. The most important factor affecting usefulness of weather for ski tourism is snow cover. In the summit zone of the Giant Mts. snow cover is characterized by the highest depth and the longest duration. Mean annual frequency of snow cover on Śnieżka is 185 days (Głowicki, 2005; Błażejczyk, 2019). High number of days with snow cover is also noticed in the Isera Mts., mainly because of very high winter precipitations (Błaś \& Sobik, 2005). Snow cover suitable for skiing (>10 cm) in the summit zone occurs during over $80 \%$ days from November till April. The highest parts of the mountains are also characterized by the most favorable snow conditions for downhill skiing (Miszuk et al., 2012) also are characterized by very high tourist traffic. Therefore, high number of tourists is exposed to negative impact of extreme weather conditions, especially in the cold season. Previous analysis on biometeorological conditions of the highest parts of the Western Sudetes (Miszuk, 2008; Miszuk et al., 2012, 2016) and the Tatra Mts. (Błażejczyk \& Kunert, 2010; Błażejczyk et al., 2013; Pełech, 2013a, b) showed, that especially during cold season, negative impact of intensive cold stress is noticed. Similar biometeorological features are also observed for the Alps and other European mountain regions (Zaninović et al., 2006; Oehler \& Matzarakis, 2007; Ketterer \& Matzarakis, 2010; Matzarakis, 2010;
Matzarakis et al., 2010, 2012; Amiranashvili et al., 2015), where strong impact of cold stress during the cold season is one of the most crucial factors. On the other hand, many of these regions are characterized by favorable snow conditions and are popular for ski recreation. In summer season, number of days with cold stress is still high, however increased frequency of thermoneutral conditions is noticed. Heat stress is rarely observed. In the highest alpine zones, cold stress prevails while heat stress does not occur at all.

The main goal of the article is to evaluate the impact of weather conditions on tourism and recreation in the region of Western Sudetes. In these purpose WSI (Weather Suitability Index), was used. Additionally, the results obtained with use of WSI were compared to UTCI (Universal Thermal Climate Index) to examine how the results of climate-related index correspond to the modern human heat load index. The results of the analysis can be a supplement for tourist guide-books and contribute to increase knowledge on the impact of severe climate conditions in the mountains on both human health and tourism issues.

\section{Data and methods}

Meteorological data from IMGW-PIB stations in the region was the basis for the characteristics of bioclimate conditions and their impact on human organism and tourism. Three stations were taken into consideration: Śnieżka, Jelenia Góra and Legnica. The first two are located in the mountain area of Western Sudetes. The summit zone is represented by Śnieżka (1603 m a.s.I.) while Jelenia Góra (342 m a.s.l.) signified its lower parts. Legnica (122 m a.s.l.) represents lowlands located north from the Sudetes Mts (Fig. 1). The data concerned the period of 1971-2015 and was mainly related to 12.00 UTC. It included air temperature, relative humidity, wind speed and cloudiness. In terms of evaluation of radiation conditions, sun angle data was also considered. In order to assess tourism-climate conditions, additional daily data on maximum 


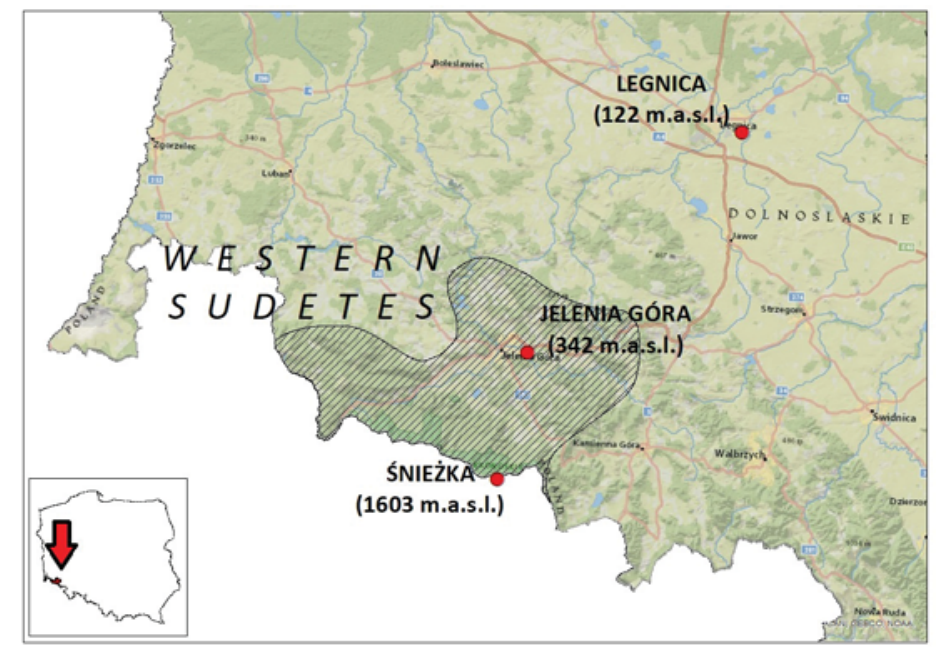

Figure 1. Location of measuring stations in the Western Sudetes and adjacent lowlands

and minimum air temperature, precipitations and snow cover was taken into consideration.

In case of tourism and recreation, the impact of weather conditions was evaluated with the use of WSI (Weather Suitability Index). It is calculated on the basis of MENEX model (Błażejczyk, 2004, 2006; Błażejczyk \& Kunert, 2011) and takes into consideration both thermal sensations and the impact of selected meteorological variables (daily air temperature amplitudes, precipitation, snow cover). The calculations of WSI were carried out with the use of BioKlima 2.6 software package and were based on the results of bio-thermal weather classification. According to WSI settings, values of this index were calculated for five types of climatotherapy, tourism and recreation: sun baths, air baths, mild recreation, intensive recreation and ski tourism. The first two forms concern climatotherapy, while mild and intensive recreation are related to different types of activities (walks, trekking, cycling), characterized by different metabolic rates. Calculation of WSI for ski tourism is focused on assessment of favorability of weather conditions for cross-country skiing. Such various spectrum of climatotherapy, tourism and recreation is extremely important as the Western Sudetes are known as the region of health resorts (i.e. Cieplice-Zdrój, Świeradów-Zdrój, etc.) as well as are popular for tourism and sports activity, including skiing. WSI for each of the mentioned forms was calculated as mean values for each day in a year (WSI avg $_{\text {g }}$. Subsequently, the values of WSI ${ }_{\text {ava }}$ were summarized and presented as overall favorability of weather conditions for climatotherapy, tourism and recreation (WSI-TOT). The categories of both WSI ${ }_{\text {avg }}$ and WSI-TOT are presented in Table 1. Frequency

Table 1. Categories of WSI $\left.\right|_{\text {ovg }}$ and WSI-TOT(according to Błażejczyk, 2004)

\begin{tabular}{|l|c|c|}
\hline \multicolumn{1}{|c|}{ Favorability of weather conditions } & WSI $_{\text {avg }}$ & WSI-TOT \\
\hline Unfavorable conditions & $<0.5$ & $<3.5$ \\
Moderately favorable conditions & $0.5-1.2$ & $3.5-5.0$ \\
Favorable conditions & $1.2-2.0$ & $5.0-6.5$ \\
Very favorable conditions & $>2.0$ & $6.5-8.0$ \\
Extremely favorable conditions & - & $>8.0$ \\
\hline
\end{tabular}


of favorable and very favorable conditions for tourism and recreation in particular decades was presented using Climate-Tourism-Information-Scheme (Matzarakis, 2007).

For of evaluations of thermal stress, UTCI (Universal Thermal Climate Index) was taken into consideration. It bases on Fiala's multi node model (Fiala et al., 2001). Regarding UTCl, values are classified into various thermal stress categories (Tab. 2). Mechanism of UTCl and its detailed descriptions is presented in numerous publications devoted to the methodology of this index (i.e. Błażejczyk et al., 2010, 2012; Jendtritzky et al., 2012).

Table 2. Thermal stress categories according to UTCl

\begin{tabular}{|l|c|}
\hline \multicolumn{1}{|c|}{ Thermal stress category } & UTCI [ $\left.{ }^{\circ} \mathrm{C}\right]$ \\
\hline Extreme heat stress & $>46.0$ \\
Very strong heat stress & 38.1 to 46.0 \\
Strong heat stress & 32.1 to 38.0 \\
Moderate heat stress & 26.1 to 32.0 \\
No thermal stress & 9.1 to 26.0 \\
Slight cold stress & 0.1 to 9.0 \\
Moderate cold stress & -13.0 to 0.0 \\
Strong cold stress & -27.0 to -13.1 \\
Very strong cold stress & -40.0 to -27.1 \\
Extreme cold stress & $<-40.0$ \\
\hline
\end{tabular}

UTCI values were calculated for each day of the studied period for 12.00 UTC. Similarly to WSI, calculations of UTCI were carried out with the use of BioKlima 2.6 software package. The calculations were the basis for evaluation of frequency of particular categories of thermal stress. In order to check out multiannual changes in bio-thermal conditions, analysis concerning trends of the UTCl categories were carried out using linear regression.

\section{Results}

\section{Sun baths}

The results of the research showed that from the point of view of weather suitability for climatotherapy, tourism and recreation, lower located zones are characterized by significantly better conditions if compared to the summit zone (Fig. 2-7). Such a situation is noticed for sun baths. In the region of Western Sudetes, WSI for sun baths (heliotherapy) is characterized by higher values in the lower hypsometric zone than at summit (Fig. 2). In Jelenia Góra and Legnica, the most frequent class of WSI is 'moderately favorable conditions'. Sun baths in this area are possible from the second decade of March till the beginning of November. In the reiaminng period of the year, significantly worse thermal, solar, wind and precipitation conditions are observed what conseqently diminishes favorability of weather for sun baths. Optimal conditions for this type of climatotherapty are noticed in the first decade of May and from August till the beginning of October ('favorable conditions'). It is a consequense of comfortable solar and thermal conditions, with low frequency of heat and cold stress, as well as relatively low number of days with precipitations. In Jelenia Góra, October is the month with high number of sunny days (Szyga-Pluta, 2017), what significantly improves weather for this type of climatotherapy. Frequency of the most valuable weather types (classes of 'favorable' and 'very favorable' conditions) in the lowlands can reach $40-50 \%$ in April/ May and $30-40 \%$ in August/September, while in the first decade of October the frequency of days with the best weather conditions for sun baths is equal to 20\% (Fig. 7). On the other hand, favorability of weather for sun baths is noticeably diminished in June and July. It results from increase in frequency of cyclonic weather, characterized by highnumber of days with strong wind, high cloudiness and precipitations. Additionally, frequent heat stress is also limiting factor in this period. In case of Śnieżka, favorability of weather for sun baths is significantly worse if compared to the lower mountain zones and the lowlands. Possible period of having sun baths ('moderately favorable conditions') is quite short and lasts from the middle of May till the second decade of September with the best conditions noticed at the break of July and August. 


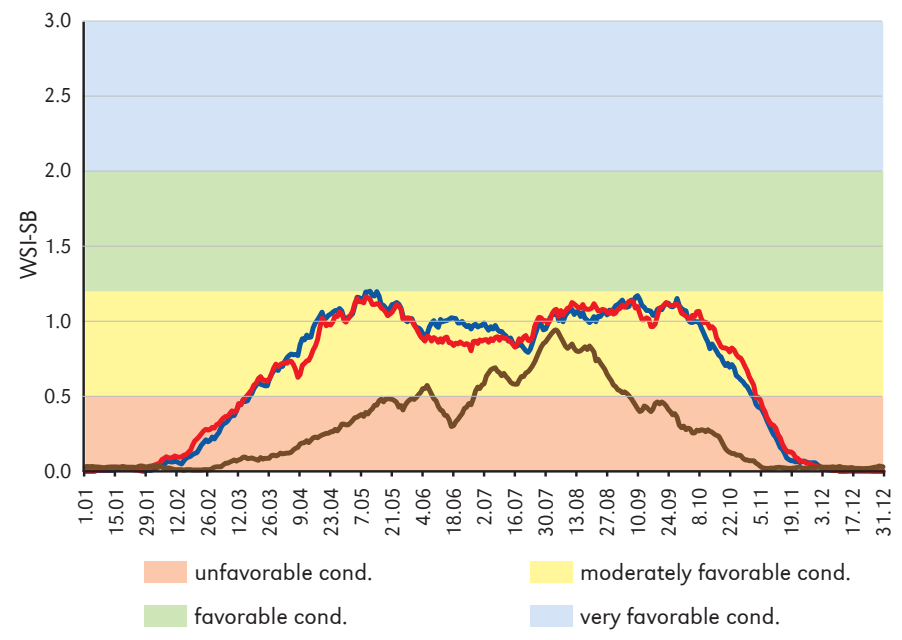

Figure 2. Favorability of weather conditions for sun baths in Śnieżka (brown), Jelenia Góra (red) and Legnica (blue) for 1971-2015 (11-day moving average)

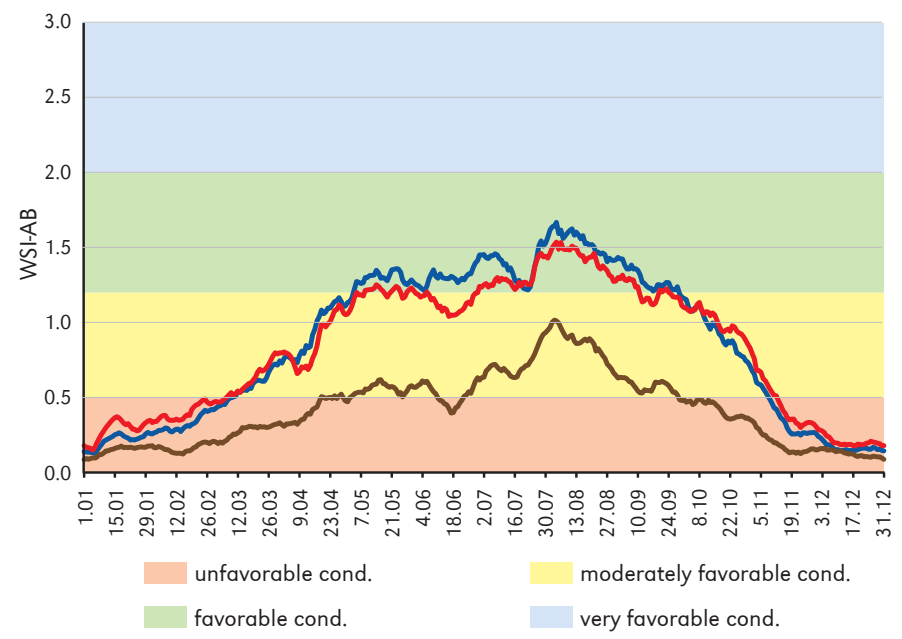

Figure 3. Favorability of weather conditions for air baths in Śnieżka (brown), Jelenia Góra (red) and Legnica (blue) for 1971-2015 (11-day moving average)

\section{Air baths}

In case of air baths (aerotherapy), the lower located areas are characterized by better weather conditions comparing to sun baths (Fig. 3). In the lower located areas, weather conditions related to at least 'favorable conditions' usually occur from the end of April till October (Fig. 7). Optimal period for air baths in the lowlands lasts from the third decade of June till the beginning of September when more than $80 \%$ of days are characterized by 'favorable' and 'very favorable conditions'. In the lower mountain zones (Jelenia Góra) this period is shortened and lasts from the third decade of July till the end of August (Fig. 7). Such conditions are caused by higher air temperature, low frequency of precipitations, decrease in wind speed and good solar condition (August is characterized 
as the month with one of the lowest cloudiness rate). The summit zone of the mountain (Śnieżka) is characterized by lower favorability of weather for air baths if compared to the lower located areas. In the period from the third decade of April till the middle of October, 'moderately favorable conditions' are noticed (Fig. 3) while days with at least 'favorable conditions' can occur (frequency of 10\%) in the first decade of August only (Fig. 7).

\section{Mild forms of recreation}

Mild recreation is connected with outdoor activities of moderate metabolic rate (i.e. walks). Therefore, the aspect of metabolism plays in that case more important role than for sun and air baths. The most noticeable difference between favorability of weather conditions for mild recreation and sun/air baths are noticed in the cold season (Fig. 4). In the lower parts of the Western Sudetes and the neighboring lowlands, the lowest values of WSI are observed form the second decade of December till the beginning of January when they are classified as 'moderately favorable conditions' (Fig. 4). All the remaining days in the year are characterized by weather conditions adequate to 'favorable conditions'. The highest frequency of classes of at least 'favorable conditions', in both lowlands and the lower mountain zones, is observed from February till the beginning of November when usually 90-100\% of days is classified as 'favorable' or 'very favorable' (Fig. 7). In case of mild recreation heat stress can cause overheating of human organism. During the summer months, WSI values for mild recreation are diminished because of increased intensity of heat stress (however it does not change the class of favorability). In the summit zone, weather related to 'moderately favorable conditions' is predominant from the beginning of November till the middle of April. In warm season, 'favorable conditions' are noticed. The most optimal period is shorter than in the lower located areas. Frequency of days with at least 'favorable conditions', reaching 90\% and more, is noticed from the third decade of April till the beginning of September, except some decades in May and June (Fig. 7).

\section{Intensive forms of recreation}

Intensive forms of recreation, like trekking or cycling, are concerned with very high metabolism rate. Such intensity can lead to organism overheating. Thus, in case of intensive form of recreation, winter cold stress does not affect usefulness of weather conditions and very

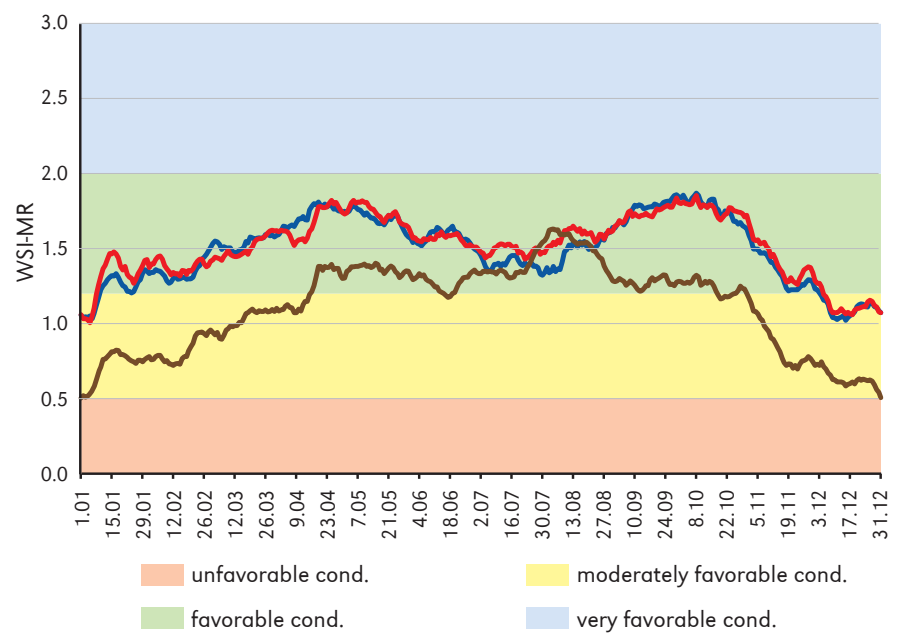

Figure 4. Favorability of weather conditions for mild recreation in Śnieżka (brown), Jelenia Góra (red) and Legnica (blue) for 1971-2015 (11-day moving average) 
high WSI values in the lower located regions are observed in the cold half-year (Fig. 5). In Legnica and Jelenia Góra, from the second decade of September till the first decade of May, WSI is classified into the class of 'very favorable conditions'. In the warm season, favorability of weather conditions for intensive forms of recreation is diminished, because of high metabolic rate that significantly increases the risk of overheating. In case of the summit zone, heat stress does not play that important role. On the other hand, cold stress during the cold season is still very important factor consequently results in totally different annual course of WSI if compared to the lower regions. On Śnieżka, in spite of cold stress, sever winds and precipitation in the period between the first decade of November and the middle of March, class of 'favorable conditions' is usually observed. In the warm season, optimal conditions ('very favorable') are noticed in the third decade of April and from the end of September till the first half of October. Unlike in the lower located areas, heat stress is not a crucial factor in the summit zone. Taking into consideration classes of at least 'favorable conditions', all the stations representing whole hypsometric profile are characterized by frequency exceeding 90\% almost throughout the year (Fig. 7).

\section{Ski tourism}

In terms of evaluation of weather for skiing, snow cover is not the only meteorological variable that affects its usefulness. The results showed that the summit of Śnieżka, is characterized by the most favorable conditions for skiing, and best period for this type of recreation is shifted from winter to spring months (Fig. 6). Such course of WSI on Śnieżka is caused by different bio-thermal and precipitation conditions. In the wintertime, low air temperature and high wind speed cause intensification of cold stress that negatively affects human organism. Additionally, increased frequency of precipitation is noticed during winter months. During spring, bio-thermal conditions are not that harmful while number of days with precipitations decreases. Simultaneously, snow cover depth is still sufficient for skiing. Therefore, taking into consideration all weather components, the 'favorable' conditions for ski tourism in the summit zone are noticed between the third decade of February and the beginning of May. The highest frequency of days with 'favorable' and 'very favorable conditions' is observed in April (when it is equal to $90-100 \%$ ) as well as from third decade of February till the end of March and in the beginning of May (5080\%) (Fig. 7). 'Moderately favorable conditions'

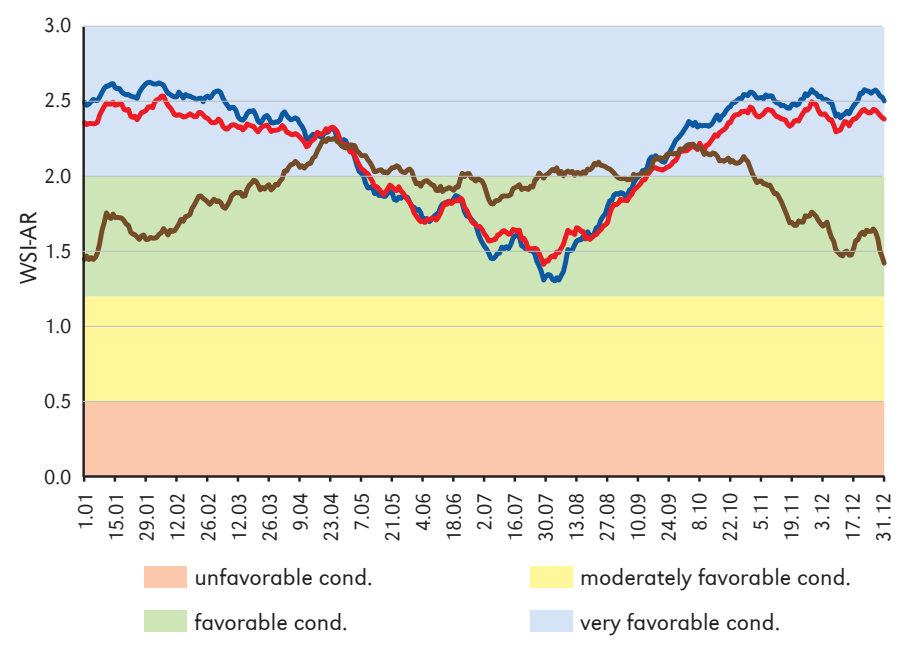

Figure 5. Favorability of weather conditions for intensive recreation in Śnieżka (brown), Jelenia Góra (red) and Legnica (blue) for 1971-2015 (11-day moving average) 


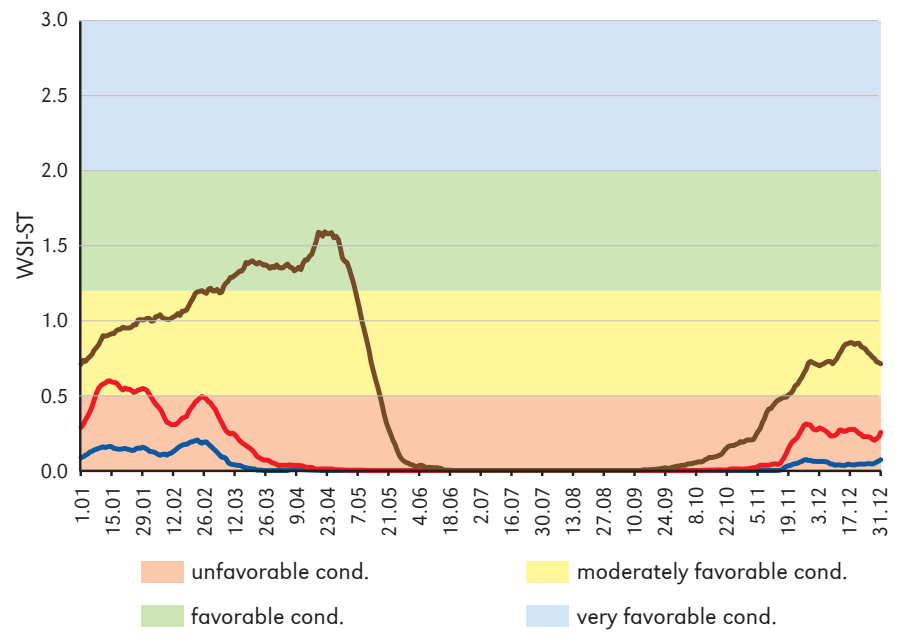

Figure 6. Favorability of weather conditions for ski tourism in Śnieżka (brown), Jelenia Góra (red) and Legnica (blue) for 1971-2015 (11-day moving average)
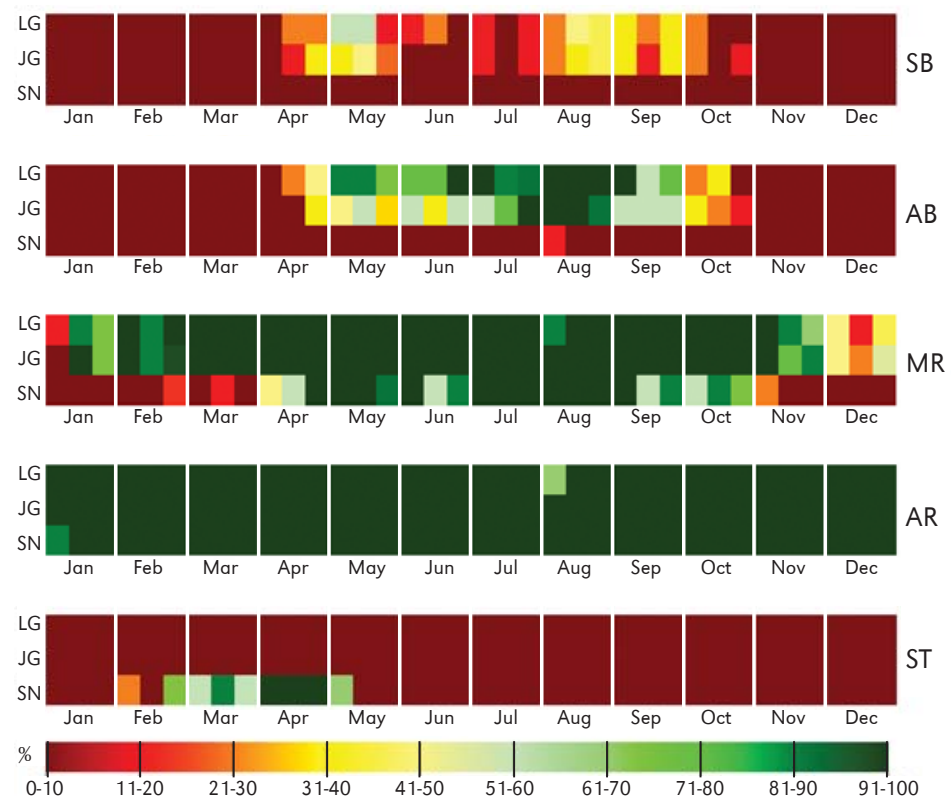

Figure 7. Frequency of 'favorable' and 'very favorable' conditions in particular decades, according to WSI (WSI $\geq 1,2$ ), for sun baths (SB), air baths (AB), mild recreation (MR), intensive recreation (AR) and ski tourism (ST) in Legnica (LG), Jelenia Góra (JG) and Śnieżka (SN) for 1971-2015

are noticed from the second decade of November till the second decade of February and in the second decade of May (Fig. 6). In the lower located areas, usefulness of weather for skiing is significantly lower. In Jelenia Góra 'moderately favorable conditions' occur only in the second and third decade of January and at the end of February. In case of the lowlands (Legnica), 'unfavorable conditions' are noticed throughout the year. 


\section{Overall weather favorability for climatotherapy, tourism and recreation}

Annual course of WSI considering all the discussed forms (WSI-TOT) shows that the lower mountain areas and the lowlands are characterized by the most favorable weather conditions in the warm season, especially in spring and autumn (Fig. 8). From March till the beginning of November values of WSITOT are adequate to 'very favorable conditions'. The highest WSI-TOT occurs at the end of September. and at the break of April and May During wintertime, the most important limiting factors are cold stress (resulting from thermal, wind and solar conditions) and high frequency of precipitations. Diminishing values of WSI-TOT in the summer months is an effect of heat stress and increased frequency of cyclonic types of weather in the first weeks of the summer.

In case of the summit zone, the best overall conditions are noticed during two periods: from the second decade of April till the second decade of May and from the last days of July till the second decade of August ('very favorable conditions'). In spring high WSI-TOT results from relatively comfortable thermal conditions as well as very good conditions for skiing. In August, the most favorable conditions for climatotherapy (sun baths, air baths) and mild recreation are noticed, what consequently increases total usefulness of weather in this period.

\section{Bio-thermal conditions according to UTCI}

Presented above analysis showed that weather favorability for tourism is strongly dependent on bio-thermal conditions. It concerns all the discussed forms of tourism and recreation. One of the most popular index used for evaluation of bio-thermal conditions is UTCl. In the discussed region, annual structure of thermal stress in the lowlands and lower mountain zones is similar (Fig. 9-10). No thermal stress class is the most frequent, it predominates especially in the warm season. During summertime, moderate and strong heat stress can occur, whereas very strong heat stress can occasionally appear in Legnica. In case of the cold season, the classes of slight and moderate cold stress are the most frequent. The summit zone is characterized by different conditions (Fig. 11). Cold stress prevails throughout the year, while heat stress does not appear at all. Weather types of moderate, strong and very strong cold

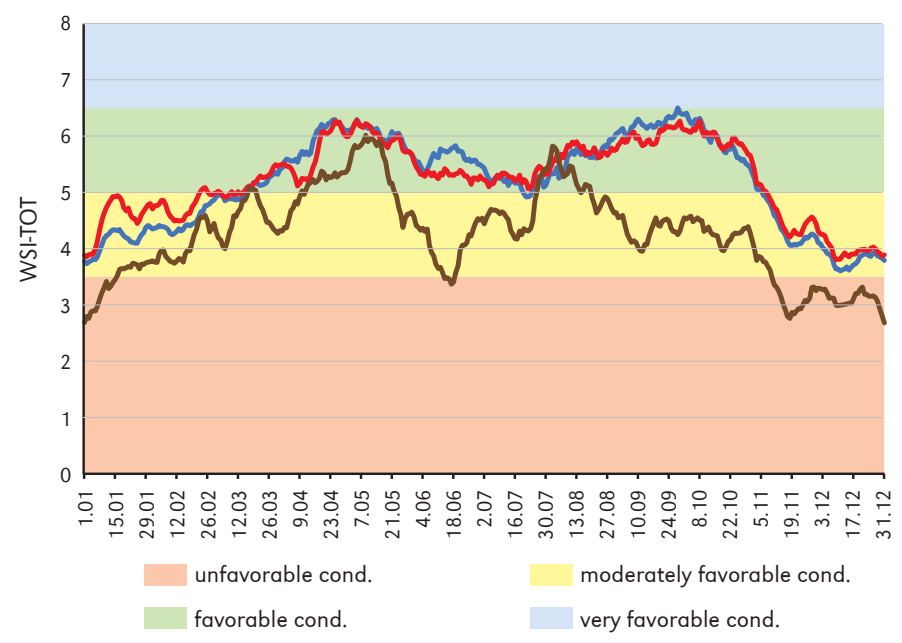

Figure 8. Overall favorability of weather conditions for tourism and recreation in Śnieżka (brown), Jelenia Góra (red) and Legnica (blue) for 1971-2015 (11-day moving average) 


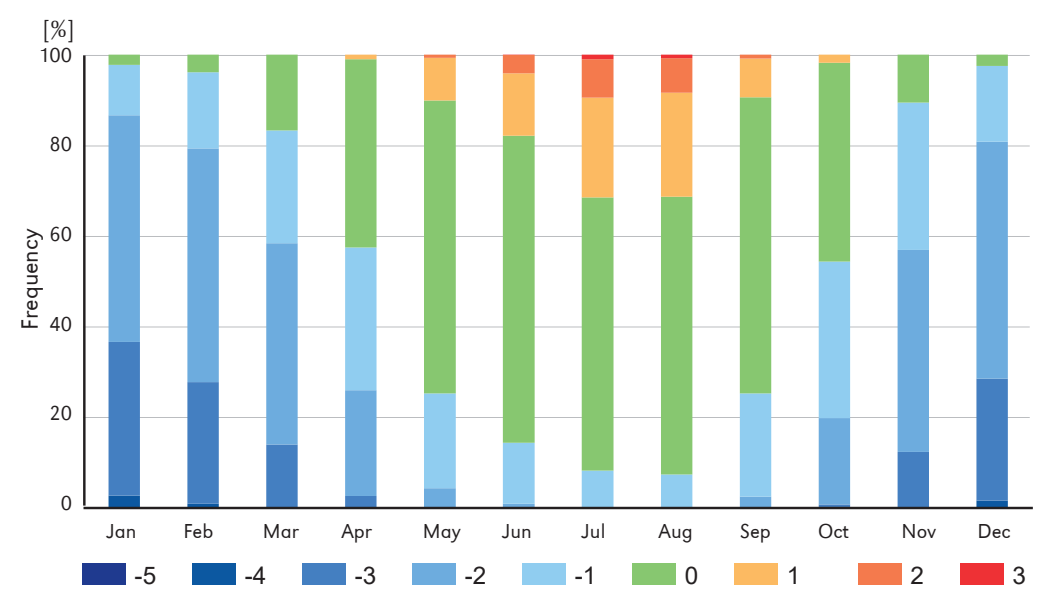

Figure 9. Frequency of UTCl categories in Legnica in 1971-2015. Thermal stress categories: extreme cold stress (-5), very strong cold stress (-4), strong cold stress (-3), moderate cold stress (-2), slight cold stress (-1), no thermal stress (0), moderate heat stress (1), strong heat stress (2), very strong heat stress (3)

stress (also no thermal stress in the summer) are the most frequent in the warm season, while significant number of days with extreme cold stress is noticed between November and March. Such bio-thermal conditions result from very low values of air temperature, high wind speed and higher cloudiness than in the lower located areas. Therefore, differentiation in bio-thermal conditions between the summit zone and the lowlands and lower mountains zones has a significant impact on variability in favorability of weather conditions for tourism in these hypsometric zones.

Analysis focused on climate changes showed that significant changes in air temperature had been noticed over the last decades in the discussed region (Migała et al., 2015; Błażejczyk, 2019). Thus, such changes could also modify bio-thermal conditions and consequently usefulness of weather for tourism and recreation. Analysis concerning changes in frequency of paticular classes of thermal stress, according to UTCl in 19712015 , showed that the number of days with thermoneutral cinditions in all hypsometric zones has increased in the last decades, while weather situation related to cold stress has been characterized by decreasing tendency (Tab. 3). Statistical significance was noticed for trends concerning thermoneutral conditions (for all of the cosidered stations), strong cold stress (Jelenia Góra), very strong cold stress (Jelenia Góra) and extreme cold stress (Śnieżka). The results of the analysis show that the rate of increase in frequency of no thermal stress category varied from 3 days per 14 years on Śnieżka to about 4 days per 11 years in Legnica and Jelenia Góra. In terms of cold stress, the most intensive changes have been observed for extreme cold stress on Śnieżka. The rate amounted also to 4 days per 11 years. In Jelenia Góra, frequency of two categories characterized by statistical significance has decreased about 2 days per decade (strong cold stress) and 1 day per 16 years (very strong cold stress). The remaining categories of cold stress were in most cases also characterized by decreasing trends, however no statistical significance was noticed. No statistical significance was also observed for trends related to heat stress categories. Such changes in thermal stress categories can influence usefulness of weather for climatotherapy, tourism and recreation. This concerns especially the forms that are strongly dependent on bio-thermal conditions. 


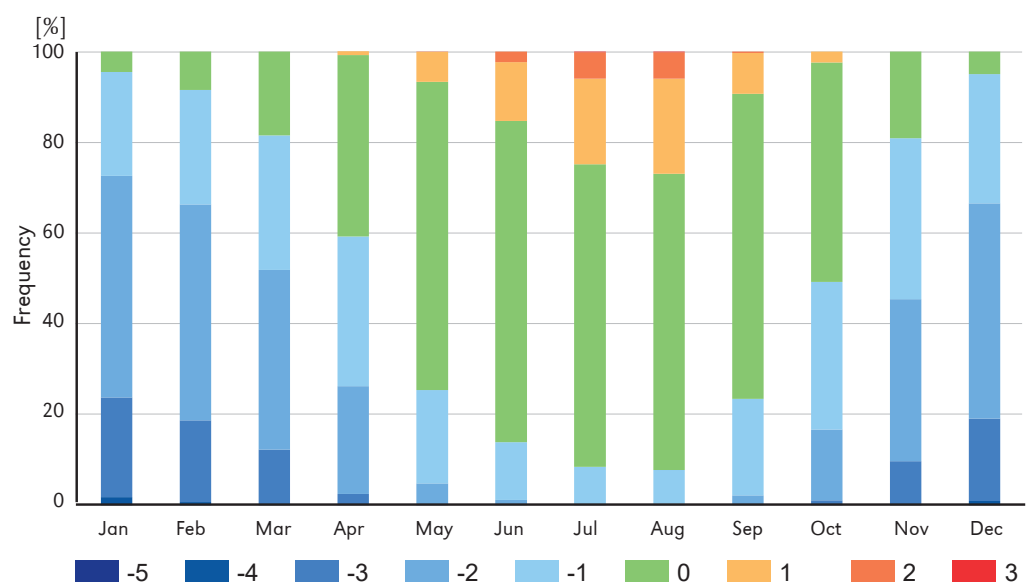

Figure 10. Frequency of UTCl categories in Jelenia Góra in 1971-2015 (thermal stress categories as in Fig. 9)

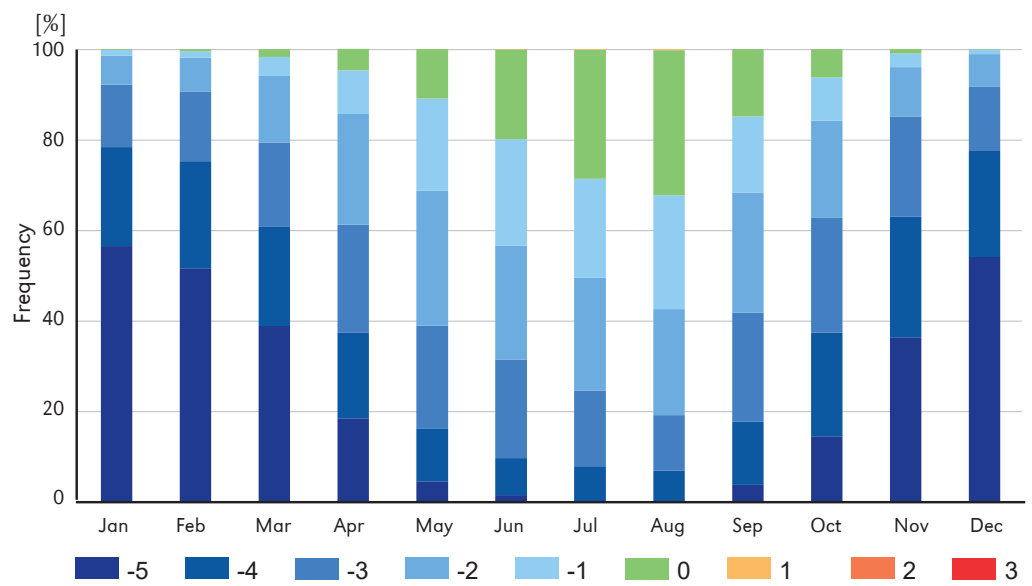

Figure 11. Frequency of UTCl categories on Śnieżka in 1971-2015 (thermal stress categories as in Fig. 9)

Table 3. Changes rate (per decade) of annual frequency of days with particular UTCl categories in Legnica (LG), Jelenia Góra (JG) and Śnieżka (SN) in 1971-2015 (statistical significance at 0.05 marked in bold)

\begin{tabular}{|l|c|c|c|c|c|c|c|c|c|}
\hline & $\begin{array}{c}\text { Extreme } \\
\text { cold stress }\end{array}$ & $\begin{array}{c}\text { Very } \\
\text { strong cold } \\
\text { stress }\end{array}$ & $\begin{array}{c}\text { Strong cold } \\
\text { stress }\end{array}$ & $\begin{array}{c}\text { Moderate } \\
\text { cold stress }\end{array}$ & $\begin{array}{c}\text { Slight cold } \\
\text { stress }\end{array}$ & $\begin{array}{c}\text { No ther- } \\
\text { mal stress }\end{array}$ & $\begin{array}{c}\text { Moderate } \\
\text { heat stress }\end{array}$ & $\begin{array}{c}\text { Strong } \\
\text { heat stress }\end{array}$ & $\begin{array}{c}\text { Very } \\
\text { strong } \\
\text { heat stress }\end{array}$ \\
\hline LG & - & -0.3 & 0.4 & -2.2 & -1.8 & $\mathbf{3 . 7}$ & -0.6 & 0.6 & 0.2 \\
JG & - & -0.6 & -2.2 & -0.9 & -0.8 & $\mathbf{3 . 6}$ & 0.1 & 0.8 & 0.0 \\
SN & $-\mathbf{3 . 6}$ & -1.1 & -0.7 & 1.8 & 1.2 & $\mathbf{2 . 4}$ & 0.0 & - & - \\
\hline
\end{tabular}




\section{Discussion and conclusions}

The presented analysis on the impact of weather conditions on climatotherapy, tourism and recreation in the Western Sudetes showed significant differences between the summit zone and the lower located areas. It concerns all of the considered forms of recreation. Comparing these two zones, the summit zone of the mountains is in some periods characterized by more favorable conditions for very active tourism in months when heat stress can often occur in the lower parts. On the other hand, the highest parts of the Western Sudetes are characterized by lower usefulness during cold season. In case of climatotherapy (sun baths, air baths), the lower parts of the mountains and the lowlands are more favorable regions in comparison to the summit zone throughout the year. In terms of ski tourism, altitude is the most important factor due to higher frequency and depth of snow cover.

Considering all the discussed forms of climatotherapy, tourism and recreation, annual course of weather suitability in the lower located area in the Western Sudetes is similar to other lowland (Koźmiński et al., 2007; Radzka \& Dragańska, 2015; Mąkosza, 2016; Wereski, 2018) and mountainous regions of Poland (Błażejczyk \& Matzarakis, 2007; Wereski, 2012; Wereski \& Demczuk, 2015). Comparable results were also noticed in the case of the lowlands and mountainous areas of Saxony (Miszuk et al., 2016). The most favorable weather conditions for sun and air baths are noticed there in the warm season while the optimum for active recreation is shifted to spring/autumn (mild recreation) or to the cold season (intensive recreation). In case of the summit zone of the Giant Mts., significantly lower WSI for sun and air baths, in comparison to the lower located areas, are a result of high frequency of cold stress, frequent precipitations as well as high cloudiness and wind speed (Szczepankiewicz-Szmyrka \& Mielcarek, 1997; Dubicka \& Głowicki, 2000; Błaś \& Sobik, 2005). Therefore, the best conditions for sun and air baths are noticed in the period when high frequency of thermal comfort is observed. Furthermore, in the discussed period, cloudiness and wind speed are also characterized by low values what increases WSI on Śnieżka. The most favorable conditions on Śnieżka for most forms of recreation occur in April-October period when the lowest frequency of cold stress is observed. It is also adequate to the period with the lowest frequency of cold stress, assessed with the method of CTIS, noticed for other high european mountains (Oehler \& Matzarakis, 2007; Ketterer \& Matzarakis, 2010; Matzarakis 2010; Matzarakis et al., 2010, 2012). Similarly to Śnieżka, the highest number of days with thermal comfort in these regions is also observed in the summer season while heat stress hardly ever occurs. Optimal weather conditions for tourism in the summer season in the high mountains are also noticed in terms of $\mathrm{TCl}$ index (Perch-Nielsen et al., 2010; Amiranashvili et al., 2015).

Comparing the results for the summit zone between the Western Sudetes and the Tatra Mts., favorability of weather conditions for considered tourist forms is similar (Błażejczyk \& Kunert, 2010; Błażejczyk et al., 2013; Pełech, 2013b). It also concerns ski tourism. Optimal conditions for this type of recreation are shifted from winter to spring months. In these terms, Śnieżka is similar to Kasprowy Wierch (1987 m a.s.I.) and Hala Gąsienicowa (1520 m a.s.l.) in the Tatra Mts. where optimal weather conditions for skiing are noticed in the spring season (Pełech, 2013b). Favorable conditions for skiing during spring months are also observed in the higher zones in other European mountains, i.e. in the Alps or in the Black Forest (Ketterer \& Matzarakis, 2010; Matzarakis et al., 2010).

Resemblances between the lower parts of the Western Sudetes and other Polish regions are also noticed for UTCl. The structure of frequency of UTCl categories in the lower parts of the Western Sudetes is similar to other lower located regions (Lindner-Cendrowska, 2013; Nowosad et al., 2013; Dobek \& Krzyżewska, 2015; Bryś \& Ojrzyńska, 2016; Półrolniczak et al., 2016). However, it does not 
concern the summit zone that is characterized by severe bio-thermal conditions that are significantly different from the lower parts of the discussed area and other mountain regions of Poland (Nowosad et al., 2013). Frequency of the most extreme cold stress on Śnieżka is even higher than on Hala Gasienicowa in the Tatra Mts. (Błażejczyk \& Kunert, 2010; Błażejczyk et al., 2013). The most noticeable feature is very high frequency of weather types that are concerned with extreme cold stress. That makes this area very uncomfortable in terms of the influence of weather on human organism. It is very important considering high popularity of this area as a tourist region, especially during wintertime when cold stress is most intensive. Consequently, each year very high number of tourist is vulnerable to cold stress impact.

In terms of changes in particular categories of thermal stress assessed with the use of $\mathrm{UTCl}$, decreasing tendency of cold stress and increasing frequency of thermoneutral conditions have been noticed over the last decades. If such trends continue, weather favorability for tourism and recreation can be improved in the future. It concerns especially the forms of recreation that are strongly affected by cold stress in the cold season: mild recreation and ski tourism. Increase in frequency of no thermal stress category can contribute to prolongation of the period suitable for performing particular forms of climatotherapy and recreation. Decreasing trends of cold stress categories were also observed for the coastal region of Poland in 1981-2010 (Półrolniczak et al., 2016). It should be emphasized that such a tendency is also projected for the future period, including discussed area (Schwarzak et al., 2014; Miszuk et al., 2016) and other European regions (Matzarakis et al., 2007; Oehler \& Matzarakis, 2007). On the other hand, no statistically significant trends for heat stress were observed for the discussed area, whereas such tendencies occurred in some other Polish regions for previous periods (Półrolniczak et al., 2016; Krzyżewska et al., 2020; Tomczyk \& Owczarek, 2020).

The information of biometeorological conditions, concerning the risk caused by extreme weather, could be included in tourist folders and book-guides in order to increase awareness among the persons visiting the region. Additionally, information on bio-thermal conditions and favorability of weather for various types of climatotherapy, tourism and recreation can be published as weather calendars that could show various usefulness of weather conditions for particular periods of the year.

Editors' note:

Unless otherwise stated, the sources of tables and figures are the authors', on the basis of their own research.

\section{References}

Amiranashvili, A., Chargazia, K., Matzarakis, A., Kartvelisgvili, L. (2015). Tourism Climate Index in the coastal and mountain locality of Adjara, Georgia. International Conference Sustainable Mountain Regions Make Them Work, Borovets Resort, Sofia, Bulgaria, 14-16 May 2015, 238-244. https://www.researchgate.net/publication/283301273

Błaś, M., Sobik, M. (2005). Osobliwości klimatu Karkonoszy i Gór Izerskich. In K. Krzemień, J. Trepińska, A. Bokwa (Eds.), Rola stacji terenowych w badaniach geograficznych (pp. 109-122). Kraków, Poland: IGiGP UJ.

Błażejczyk, K. (2004). Bioklimatyczne uwarunkowania rekreacji i turystyki w Polsce. Prace Geograficzne, 192, Warsaw: IGiPZ PAN. 
Błażejczyk, K. (2006). MENEX_2005 - the Revised Version of Man-Environment Heat Exchange Mode. www.igipz.pan.pl/geoekoklimat/blaz/menex.htm

Błażejczyk, K. (2019). Sezonowa i wieloletnia zmienność niektórych elementów klimatu w Tatrach i Karkonoszach w latach 1951-2015. Przegląd Geograficzny, 91(1), 59-80.

https://doi.org/10.7163/PrzG.2019.1.2

Błażejczyk, K., Baranowski, J., Błażejczyk, A., Szmyd, J. (2013). Klimat i bioklimat Hali Gqsienicowej. In Z. Rączkowska, A. Kotarba (Eds.), Dolina Suchej Wody w Tatrach: środowisko i jego współczesne przemiany (pp. 193-200). Prace Geograficzne, 239, Warsaw: IGiPZ PAN.

Błażejczyk, K., Bröde, P., Fiala, D., Havenith, G., Holmer, I., Jendritzky, G., Kampmann, B. (2010). UTCI - nowy wskaźnik oceny obciążeń cieplnych. Przegląd Geograficzny, 82(1), 49-71. https://doi.org/10.7163/PrzG.2010.1.2

Błażejczyk, K., Epstein, Y., Jendritzky, G., Staiger, H., Tinz, B. (2012). Comparison of UTCI to selected thermal indices. International Journal of Biometeorology, 56(3), 515-535. https://doi.org/10.1007/s00484-011-0453-2

Błażejczyk, K., Kunert, A. (2010). Obciq̨żenie cieplne organizmu człowieka podczas letnich i zimowych wędrówek po Tatrach. In Z. Krzan (Ed.), Nauka a zarządzanie obszarem Tatr i ich otoczeniem, Tom III: Człowiek i Środowisko (pp. 61-68). Zakopane: Tatrzański Park Narodowy.

Błażejczyk, K., Kunert, A. (2011). Bioklimatyczne uwarunkowania rekreacji i turystyki w Polsce. Monografie, 13, Warsaw: IGiPZ PAN.

Błażejczyk, K., Matzarakis, A. (2007). Assessment of bioclimatic differentiation of Poland based on the human heat balance. Geographia Polonica, 80(1), 63-82.

Bryś, K., Ojrzyńska, H. (2016). Bodźcowość warunków biometeorologiczych we Wrocławiu. Acta Geographia Lodziensa, 104, 193-200.

Dobek, M., Krzyżewska, A. (2015). Wybrane zagadnienia z bioklimatu Lublina. Annales Universitatis Mariae Curie-Skłodowska, Sectio B, 70(2), 117-129. https://doi.org/10.17951/b.2015.70.2.117

Dubicka, M., Głowicki, B. (2000). Air temperature and cloudiness at Śnieżka between 1901 and 1998. Prace Geograficzne Uniwersytetu Jagiellońskiego, 107, 207-212.

Fiala, D., Lomas, K.J., Stohrer, M. (2001). Computer prediction of human thermoregulatory and temperature responses to a wide range of environmental conditions. International Journal of Biometeorology, 45(3), 143-159. https://doi.org/10.1007/s004840100099

Głowicki, B. (2005). Klimat Karkonoszy. In M. Mierzejewski (Ed.), Karkonosze. Przyroda nieożywiona i człowiek, Acta Universitatis Wratislaviensis, 2823, 381-397.

Jendtritzky, G., de Dear, R., Havenith, G. (2012). UTCl - why another thermal index? International Journal of Biometeorology, 56(3), 421-428. https://doi.org/10.1007/s00484-011-0513-7

Ketterer, C., Matzarakis, A. (2010). The tourism climate of Engadin, Switzerland. In A. Mazarakis, H. Mayer, F.-M. Chmielewski (Eds.), Proceedings of the 7th Conference on Biometeorology (pp. 398403). Freiburg, Germany: Albert-Ludwigs-University of Freiburg. https://doi.org/10.6094/UNIFR/15268

Koźmiński, C., Mąkosza, A., Michalska, B. (2007). Bioklimatyczne warunki wypoczynku w rejonie jeziora Miedwie w półroczu ciepłym. Przeglad Naukowy. Inżynieria i Kształtowanie Środowiska, 16(3), 3-37.

Krzyżewska, A., Wereski, S., Dobek, M. (2020). Summer UTCI variability in Poland in the twenty first century. International Journal of Biometeorology. https://doi.org/10.1007/s00484-020-01965-2

Lindner-Cendrowska, K. (2013). Assessment of bioclimatic conditions in cities for tourism and recreational purposes (a Warsaw case study). Geographia Polonica, 86(1), 55-66.

https://doi.org/10.7163/gpol.2013.7

Matzarakis, A. (2007). Assessment method for climate and tourism based on daily data. In A. Matzarakis, C.R. de Freitas, D. Scott (Eds.), Developments in tourism climatology (pp. 52-58). Freiburg, Germany: Commission on Climate, Tourism and Recreation International Society of Biometeorology. 
Matzarakis, A. (2010). Assessment of Weather and Climate for Tourism and Health in the Alps. In Metropolises and "their" Alps. Proceedings of the Forum Alpinum 6 to 10 October 2010, Munich (pp. 35-38). Germany: Bayerische Akademie der Wissenschaften.

Matzarakis, A., Koch, E., Rudel, E. (2007). Analysis of summer tourism period for Austria based on climate variables on daily basis. In A. Matzarakis, C.R. de Freitas, D. Scott (Eds.), Developments in tourism climatology (pp. 122-128). Freiburg, Germany: Commission on Climate, Tourism and Recreation International Society of Biometeorology.

Matzarakis, A., Hammerle, M., Koch, E., Rudel, E. (2012). The climate tourism potential of Alpine destinations using the example of Sonnblick, Rauris and Saltzburg. Theoretical and Applied Climatology, 110, 645-658. https://doi.org/10.1007/s00704-012-0686-y

Matzarakis, A., Schneevoigt, T., Matuschek, O., Endler, C. (2010). Climate-Tourism-Information-Scheme (CTIS). In A. Matzarakis, H. Mayer, F.-M. Chmielewski (Eds.), Proceedings of the 7th Conference on Biometeorology (pp. 392-397). Freiburg, Germany: Albert-Ludwigs-University of Freiburg.

Mąkosza, A. (2016). Zastosowanie biometeorologicznej klasyfikacji warunków pogodowych w rekreacji i turystyce w Polsce środkowo-zachodniej. Przeglad Geograficzny, 88(3), 369-382.

https://doi.org/10.7163/przg.2016.3.5

Migała, K., Urban, G., Tomczyński, K. (2015). Long-term air temperature variation in the Karkonosze mountains according to atmospheric circulation. Theoretical and Applied Climatology, 125, 337-351. https://doi.org/10.1007/s00704-015-1468-0

Miszuk, B. (2008). Charakterystyka warunków bioklimatycznych Karkonoszy z punktu widzenia różnych form turystyki i rekreacji. Prace Geograficzne IGiGP UJ, 120, 79-91.

Miszuk, B., Otop, l., Owczarek, M. (2012). Warunki bioklimatyczne jako czynnik kształtujacy potencjał rekreacyjny Sudetów. Przegląd Geograficzny, 84(3), 437-446. https://doi.org/10.7163/PrzG.2012.3.7

Miszuk, B., Otop, I., Strońska, M., Schwarzak, S., Surke, M. (2016). Tourism-climate conditions and their future development in the Polish-Saxon border area. Meteorologische Zeitschrift, 25(4), 421-434. http://doi.org/10.1127/metz/2016/0700

Nowosad, M., Rodzik, B., Wereski, S., Dobek, M. (2013). The UTCI Index in Lesko and Lublin and its circulation determinants. Geographia Polonica, 86(1), 29-36. http://doi.org/10.7163/GPol.2013.4

Oehler, K., Matzarakis, A. (2007). Climate change and tourism potential in the Black Forest - a tourism and climate approach for forest areas. In A. Matzarakis, C. R. de Freitas, D. Scott (Eds.), Developments in tourism climatology (pp. 267-273). Freiburg, Germany: Commission on Climate, Tourism and Recreation International Society of Biometeorology.

Otop, I., Miszuk, B. (2011). Cechy klimatu Śnieżki. In J. Gierczak (Ed.), 130 lat obserwacji na Śnieżce (pp. 23-54). Wrocław: Instytut Meteorologii i Gospodarki Wodnej.

Pełech, S. (2013a). Warunki biotermiczne w Tatrach Polskich. Prace Geograficzne, 133, 7-19, https://doi.org/10.4467/20833113PG.13.07.1097

Pełech, S. (2013b). Bioklimatyczne uwarunkowania turystyki i rekreacji w Tatrach Polskich. In R. Pawlusiński (Ed.), Współczesne uwarunkowania i problemy rozwoju turystyki (pp. 403-412). Kraków: IGiGP UJ

Perch-Nielsen, S.L., Amelung, B., Knutti, R. (2010). Future climate resources for tourism in Europe based on the daily Tourism Climate Index. Climatic Change, 103(3-4), 363-381. https://doi.org/10.1007/s10584-009-9772-2

Półrolniczak, M., Szyga-Pluta, K., Kolendowicz, L. (2016). Bioklimat wybranych miast pasa Pobrzeży Południowobałtyckich na podstawie uniwersalnego wskaźnika obciążenia cieplnego. Acta Geographia Lodziensa, 104, 147-161.

Radzka, U., Dragańska, E. (2015). Bioklimatyczne warunki turystyki i rekreacji w województwie warmińsko-mazurskim. Olsztyn: Wydawnictwo Uniwersytetu Warmińsko-Mazurskiego w Olsztynie. 
Rogowski, M. (2015). Preferencje turystów w polskich Karkonoszach jako podstawa tworzenia produktu turystycznego obszaru. Rozprawy Naukowe Akademii Wychowania Fizycznego we Wrocławiu, 50, 152-163.

Rogowski, M. (2018). Czasoprzestrzenny rozkład ruchu turystycznego na szczycie Śnieżki w 2015 roku. Prace Geograficzne, 154, 107-125. https://doi.org/10.4467/20833113PG.18.011.9443

Schwarzak, S., Otop, I., Kryza, M. (Eds.) (2014). Projekcje klimatu, zanieczyszczenia powietrza i ładunki krytyczne w regionie granicznym Polski i Saksonii. Dresden, Germany: Sächsisches Landesamt für Umwelt, Landwirtschaft und Geologie.

Szczepankiewicz-Szmyrka, A., Mielcarek, A. (1997). Bioclimatic conditions in subalpine zone of Karkonosze Mts. Acta Universitatis Wratislaviensis, 1950(C4), 95-101.

Szyga-Pluta, K. (2017). Variation of cloudiness in the mountain region on the example of the Sudetes. Badania Fizjograficzne, Seria A, Geografia Fizyczna (A68), 205-221.

Tomczyk, A.M., Owczarek, M. (2020). Occurrence of strong and very strong heat stress in Poland and its circulation conditions. Theoretical and Applied Climatology, 139, 893-905. https://doi.org/10.1007/s00704-019-02998-3

Wereski, S. (2012). Przydatność warunków bioklimatycznych do turystyki wypoczynkowej w Solinie (1981-1998). Przeglad Geograficzny, 84(3), 447-456. https://doi.org/10.7163/PrzG.2012.3.8

Wereski, S. (2018). Ocena warunków bioklimatycznych Polski Wschodniej do wybranych form rekreacji i turystyki. Prace Geograficzne, 153, 89-103. https://doi.org/10.4467/20833113PG.18.005.8480

Wereski, S., Demczuk, P. (2015). Ocena warunków bioklimatycznych Leska pod kątem możliwości uprawiania wybranych form turystyki. In A. Wdowiak, A. Tucki (Eds.), Aspekty środowiskowo-rekreacyjne i prawne zdrowia człowieka (pp. 212-224). Włodawa: Międzynarodowe Towarzystwo Wspierania i Rozwoju Technologii Medycznej.

Zaninović, K., Matzarakis, A., Cegnar, T. (2006). Thermal comfort trends and variability in the Croatian and Slovenian mountains. Meteorologische Zeitschrift, 15(2), 243-251.

https://doi.org/10.1127/0941-2948/2006/0119 